OPEN ACCESS

Citation: I.M. El-Metwally, H.S. Saudy, M. Tawfik Abdelhamid (2021) Efficacy of benzyladenine for compensating the reduction in soybean productivity under low water supply. Italian Journal of Agrometeorology (2): 81-90. doi: 10.36253/ijam-872

Received: March 09, 2020

Accepted: June 26, 2021

Published: December 27, 2021

Copyright: (2021I.M. El-Metwally, H.S. Saudy, M. Tawfik Abdelhamid. This is an open access, peer-reviewed article published by Firenze University Press (http://www.fupress.com/ijam) and distributed under the terms of the Creative Commons Attribution License, which permits unrestricted use, distribution, and reproduction in any medium, provided the original author and source are credited.

Data Availability Statement: All relevant data are within the paper and its Supporting Information files.

Competing Interests: The Author(s) declare(s) no conflict of interest.

ORCID:

HSS: 0000-0002-6341-6156

\section{Efficacy of benzyladenine for compensating the reduction in soybean productivity under low water supply}

\author{
Ibrahim Mohamed El-Metwally ${ }^{1}$, Hani Saber Saudy ${ }^{2, *}$, Magdi Tawfik \\ ABDElHAMID $^{1}$ \\ ${ }^{1}$ Botany Department, National Research Centre, P.O. Box 12622-Dokki, El-Behos St. \\ Dokki, Cairo, Egypt \\ ${ }^{2}$ Agronomy Department, Faculty of Agriculture, Ain Shams University, P.O. Box 68- \\ Hadayek Shoubra 11241, Cairo, Egypt \\ ${ }^{*}$ Corresponding author. E-mail: hani_saudy@agr.asu.edu.eg
}

\begin{abstract}
Undoubtedly, drought is a negative consequence of climate change. Farmers have to deal with this issue and may be forced to irrigate their crops with less water than required, however reduction in productivity is anticipated. Thus, two-year field trials were conducted to assess the impact of irrigation regimes (60, 80 and $100 \%$ of crop evapotranspiration, denoted $\mathrm{ET}_{60}, \mathrm{ET}_{80}$, and $\mathrm{ET}_{100}$, respectively) and benzyladenine rates $\left(0,50,100,150\right.$ and $200 \mathrm{mg} \mathrm{L} \mathrm{L}^{-1}$, symbolized as $\mathrm{BA}_{0}, \mathrm{BA}_{50}, \mathrm{BA}_{100}, \mathrm{BA}_{150}$, $\mathrm{BA}_{200}$, respectively) on soybean. Findings clarified that the maximum increases in plant height and net assimilation rate were obtained with the interactions of $\mathrm{ET}_{100}$ or $_{\mathrm{ET}_{80} \mathrm{X}}$ $\mathrm{BA}_{200}$ or $\mathrm{BA}_{150}$ in both seasons. $\mathrm{ET}_{80} \times \mathrm{BA}_{200}$ (in both seasons) and $\mathrm{ET}_{100} \times \mathrm{BA}_{150}$ (in the first season) were as similar as $\mathrm{ET}_{100} \mathrm{x} \mathrm{BA}_{200}$ for enhancing pods number plant ${ }^{-1}$. Irrigation water use efficiency progressively increased with decreasing irrigation water amount and increasing benzyladenine rate. In conclusion, the reduction in seed yield due to lowering water supply up to $80 \%$ of crop evapotranspiration (with saving $20 \%$ of irrigation water) could be compensated using benzyladenine, $150 \mathrm{mg} \mathrm{L}^{-1}$, thus it should be involved in soybean irrigation programs.
\end{abstract}

Keywords: deficit water, growth promoters, relative growth rate, soybean oil.

\section{INTRODUCTION}

Soybean $\{$ Glycine $\max$ (L.) Merr.\} occupies a prestigious position in the global economy, since its seeds are considered a major source of protein (approximately, 38-47\%) and oil (approximately, 18-22\%) (Nakagawa et al. 2020; Tian et al. 2020), besides its importance in sustainable agriculture. In water rationalization patterns, the increase of water use efficiency should be pursued in a sustainability prospective, increasing crop productivity per unit of water used (Oweis and Hachum 2003). In this respect, farmers are obligated to irrigate their crops using less water than required (El-Bially et al. 2018; Salem et al. 2021). However, soybean production is affected by abiotic 
pressures, i.e. water deficit. Water stress is a major factor in determining crop productivity, particularly in arid and semi-arid areas. In Egypt, based on the local farmers' irrigation practice for the soybean cropping system, the optimized water consumption is $550 \mathrm{~mm} /$ total growing period (Sheteiwy et al. 2021). Water deficit conditions affect the water potential and turgor pressure of the cells and this can disturb the normal plant physiological mechanisms inducing various impacts on growth and yield parameters of the crops (Reisdorph and Koster 1999; El-Metwally et al. 2021). Soybean under drought stress at beginning of pod, beginning of seed and full seed stages resulted in substantial yield losses (Dogan et al. 2007). The photosynthetic activity of soybean plants was severely decreased (Zhang et. al. 2016) and photoinhibition increased (Sofo et al. 2009) in drought conditions. Because of severe drought stress during flowering and pod-setting stage, losses in leaf area, dry matter and seed yield per soybean plant reached 61, 67 and $77 \%$, respectively (Wei et al. 2018).

Due to application of plant growth regulators, alternations in metabolic and physiological processes in plants reflecting on flowering, fruiting, maturation, fruit drop, and defoliation were observed (Rademacher 2015). One of the most important plant growth promoters is cytokinins group which play a crucial role in plant differentiation and development (Yeh et al. 2015). In soybean, enhancement in yield was evident because of cytokinin foliar application (Soares et al. 2017). Borges et al. (2014) proved that benzyladenine as a compound of cytokinin can reduce pod abortion and improve yield of soybean. Moreover, application of benzyladenine significantly improved growth, yield, yield attributes and quality of soybean (Khaswa et al. 2014). Still, the knowledge about the potency of benzyladenine and its demeanor in soybean under drought is not sufficiently available.

Therefore, the objective of this study was to evaluate the efficacy of benzyladenina to alleviate the impacts of low water supply in soybean.

\section{MATERIALS AND METHODS}

\section{Site attributes}

The experiments were carried out under open field conditions during two years (2015 and 2016) at the experimental research and production station of National Research Centre, El-Nubaria region, Egypt (latitude $30^{\circ} 86^{\prime} \mathrm{N}$, and longitude $31^{\circ} 16^{\prime} \mathrm{E}$, and mean altitude $21 \mathrm{~m}$ above sea level). Location is typified as arid region having cool winters as well as hot dry summers with no rainfall. Mean values of weather status prevailing during soybean
Table 1. Averages of some weather data during life cycle of soybean grown at El-Nubaria region in 2015 and 2016 seasons.

\begin{tabular}{lcccc}
\hline \multirow{2}{*}{ Month } & \multicolumn{2}{c}{ Air temperature $\left({ }^{\circ} \mathrm{c}\right)$} & $\begin{array}{c}\text { Wind speed } \\
\left(\mathrm{m} \mathrm{sec}^{-1}\right)\end{array}$ & $\begin{array}{c}\text { Solar radiation } \\
\left(\mathrm{MJ} \mathrm{m}^{-2} \text { day }^{-1}\right)\end{array}$ \\
\cline { 2 - 3 } & Minimum & Maximum & & \\
\hline 2015 & & & & 27.09 \\
May & 34.6 & 17.5 & 4.43 & 29.53 \\
June & 36.2 & 19.3 & 4.73 & 29.26 \\
July & 35.5 & 19.7 & 4.74 & 27.32 \\
August & 37.1 & 20.9 & 3.93 & 23.39 \\
September & 34.4 & 19.9 & 4.30 & \\
\hline 2016 & & & & 26.59 \\
May & 32.8 & 17.1 & 4.36 & 29.43 \\
June & 36.0 & 19.3 & 4.63 & 29.16 \\
July & 36.8 & 20.5 & 4.23 & 22.89 \\
August & 38.1 & 21.5 & 4.16 & \\
September & 34.6 & 20.5 & 3.81 & \\
\hline
\end{tabular}

Table 2. Initial soil physical and chemical properties of El-Nubaria region.

\begin{tabular}{|c|c|c|c|c|c|c|c|c|}
\hline \multirow{2}{*}{$\begin{array}{l}\text { Soil } \\
\text { depth } \\
\text { (cm) }\end{array}$} & \multicolumn{3}{|c|}{$\begin{array}{c}\text { Particle size } \\
\text { distribution (\%) }\end{array}$} & \multirow[b]{2}{*}{$\begin{array}{l}\text { Texture- } \\
\text { class }\end{array}$} & \multicolumn{4}{|c|}{ Chemical properties } \\
\hline & $\begin{array}{c}\text { Coarse } \\
\text { sand }\end{array}$ & $\begin{array}{l}\text { Fine } \\
\text { sand }\end{array}$ & $\begin{array}{c}\text { Clay+ } \\
\text { silt }\end{array}$ & & $\begin{array}{l}\text { Organic } \\
\text { natter } \\
(\%)\end{array}$ & $\mathrm{pH}$ & $\begin{array}{c}\mathrm{EC} \\
(\mathrm{dS} \\
\left.\mathrm{m}^{-1}\right)\end{array}$ & $\begin{array}{c}\mathrm{CaCO}_{3} \\
(\%)\end{array}$ \\
\hline 20 & 46.1 & 48.6 & 5.3 & Sandy & 0.70 & 8.5 & 0.32 & 6.56 \\
\hline 40 & 54.2 & 39.1 & 6.7 & & 0.45 & 8.7 & 0.30 & 2.51 \\
\hline 60 & 56.2 & 37.0 & 6.8 & & 0.30 & 9.1 & 0.42 & 4.75 \\
\hline
\end{tabular}

life cycle are provided in Table 1 . Physical and chemical properties of the experimental soil are shown in Table 2.

\section{Experimental set-up}

Each experiment was established with a strip-plots design having four replicates. Three irrigation levels (60, 80 and $100 \%$ of crop evapotranspiration, ETc, denoted $\mathrm{ET}_{60}, \mathrm{ET}_{80}$, and $\mathrm{ET}_{100}$, respectively) were practiced. As well, five benzyladenine (BA) rates $(0,50,100,150$ and $200 \mathrm{mg} \mathrm{L}^{-1}$, symbolized as $\mathrm{BA}_{0}, \mathrm{BA}_{50}, \mathrm{BA}_{100}, \mathrm{BA}_{150}, \mathrm{BA}_{200}$, respectively) were sprayed twice at 45 and 60 days after sowing (DAS).

After harvesting the preceding crop (wheat), the experimental field was ploughed and ridged $(60 \mathrm{~cm}$ width) before planting. During land preparation, single super-phosphate $\left(15.5 \% \quad \mathrm{P}_{2} \mathrm{O}_{5}\right)$ was applied at a rate of $357 \mathrm{~kg} \mathrm{ha}^{-1}$. Moreover, the field was divided into experimental units of about $3.5 \mathrm{~m}$ x $3.0 \mathrm{~m}$ each. Soybean seeds (cv Giza-111) were inoculated with the specific Rhizobi- 
um strain and immediately sown in hills (2-3 seeds), 20 $\mathrm{cm}$ apart on both sides of the ridge. Sowing dates were May $18^{\text {th }}$ and $25^{\text {th }}$ in 2015 and 2016 seasons, respectively. At 20 and 35 DAS, all plots received $52.5 \mathrm{~g}$ ammonium nitrate $(33.5 \% \mathrm{~N})$ and $157.5 \mathrm{~g}$ potassium sulphate $(48 \%$ $\mathrm{K}_{2} \mathrm{O}$ ), respectively. Plants were watered through trickle irrigation system which comprised of emitters spaced $30.0 \mathrm{~cm}$ apart with discharge of $2.0 \mathrm{~L} \mathrm{~h}^{-1}$.

Based on the information provided in Table 1, FAO Penman-Monteith equation (Allen et al. 1998) was exploited to estimate the daily reference evapotranspiration $\left(\mathrm{ET}_{0}\right)$ of soybean along the growing season. Thereafter, crop evapotranspiration (ETc) was calculated with the water budget and irrigation decision support model by FAO-56. Accordingly, the quantity of irrigation water requirement was computed as elucidated by Keller and Bliesner (1990). Seasonal irrigation water applied for 2015 and 2016 seasons are shown in Table 3.

\section{Crop parameters}

At 90 DAS, plant height was measured. Also, total chlorophyll content (SPAD value) of the $4^{\text {th }}$ leaf was measured using chlorophyll meter (SPAD 502) according to Soil Plant Analysis Department Section, Minolta Camera Co., Osaka, Japan as reported by Minolta (1989). Moreover, ten plants were randomly selected from the inner rows of each plot at $60\left(t_{1}\right)$ and $90\left(t_{2}\right)$ DAS to determine relative growth rate (RGR) and net assimilation rate (NAR) as described by Hunt (1982) as follow:

$\mathrm{RGR}=\frac{\ln \mathrm{W}_{2}-\ln \mathrm{W}_{1}}{\mathrm{t}_{2}-\mathrm{t}_{1}}\left(\mathrm{~g} \mathrm{~g}^{-1}\right.$ week $\left.^{-1}\right)$

Where, $\ln =$ Natural log, $\mathrm{W}_{1}=$ Dry weight of plant $\mathrm{m}^{-2}$ recorded at time $\mathrm{t}_{1}, \mathrm{~W}_{2}=$ Dry weight of plant $\mathrm{m}^{-2}$ recorded at time $t_{2}, t_{1}$ and $t_{2}$ are the interval of time.

$\mathrm{NAR}=\frac{\left(\mathrm{W}_{2}-\mathrm{W}_{1}\right)\left(\log \mathrm{LA}_{2}-\log \mathrm{A}_{1}\right)}{\left(\mathrm{LA}_{2}-\mathrm{LA}_{1}\right)\left(\mathrm{t}_{2}-\mathrm{t}_{1}\right)}\left(\mathrm{g} \mathrm{cm}^{-2}\right.$ week $\left.^{-1}\right)$

Table 3. Seasonal irrigation water applied in soybean $\left(\mathrm{m}^{3} \mathrm{ha}^{-1}\right)$ in 2015 and 2016 seasons under various irrigation levels.

\begin{tabular}{lcc}
\hline Irrigation level & 2015 season & 2016 season \\
\hline $\mathrm{ET}_{60}$ & 2394 & 2436 \\
$\mathrm{ET}_{80}$ & 3192 & 3248 \\
$\mathrm{ET}_{100}$ & 3990 & 4060 \\
\hline
\end{tabular}

Note: $\mathrm{ET}_{60}, \mathrm{ET}_{80}$, and $\mathrm{ET}_{100}$ : irrigation level at 60,80 and $100 \%$ of crop evapotranspiration, respectively.
Where: $\mathrm{W}_{1}$ and $\mathrm{W}_{2}$ are total plant dry weight as well as $L_{1}$ and $L A_{2}$ are total leaf area at time $t_{1}$ and $t_{2}$ respectively.

At full maturity $\left(29^{\text {th }}\right.$ September in 2015 and $6^{\text {th }}$ October in 2016), plants of the experimental plots were harvested to assess pods number plant ${ }^{-1}$, seed weight plant $^{-1}$ and seed yield ha ${ }^{-1}$. According to AOAC (2012), seed oil and protein contents were estimated.

\section{Irrigation water use efficiency and regression analysis}

Depending on the computed irrigation water amounts for each irrigation level in 2015 and 2016 seasons (Table 3), irrigation water use efficiency (IWUE) for soybean crop was estimated as follow:

IWUE $=\frac{\text { Seed yield }}{\text { Irrigation water amount }}\left(\mathrm{kg} \mathrm{m}^{-3}\right)$

Thereafter, simple regression analysis between IWUE (dependent variable) and benzyladenine rate (independent variable) under different irrigation water regimes was derived as explained by Draper and Smith (1998).

\section{Statistical analysis}

Data of each season were subjected to analysis of variance (ANOVA) according to Casella (2008), using Costat software program, Version 6.303 (2004). Means separation was performed only when the F-test indicated significant $(\mathrm{P}<0.05)$ differences among the treatments, according to the Fisher's protected LSD test.

\section{RESULTS}

\section{Plant growth}

Available results in Table 4 show the significant influence of each irrigation and benzyladenine on the investigated growth traits of soybean in 2015 and 2016 seasons. In this respect, with each increase in water amount, there were progressive increases in plant height, SPAD value, RGR and NAR. Application of $\mathrm{ET}_{100}$ recorded the maximum values of RGR and NAR surpassing $\mathrm{ET}_{80}$ or $\mathrm{ET}_{60}$. The differences between $\mathrm{ET}_{100}$ and $\mathrm{ET}_{80}$ did not reach the $\mathrm{P}<0.05$ level of significance for plant height and NAR in 2016 season as well as RGR in 2015 season. Moreover, the minimal values of such traits were obtained with $\mathrm{ET}_{60}$. 
Spraying soybean plants with benzyladenine (BA) caused significant increases in plant height, SPAD value, RGR and NAR (Table 4). With increasing BA rate up to $150 \mathrm{mg} \mathrm{L}^{-1}$, all soybean growth traits progressively increased in both seasons, except RGR in 2015 season. In this respect, $\mathrm{BA}_{200}$ achieved the highest values significantly leveling with $\mathrm{BA}_{150}$.

The significant interaction of irrigation level $x$ benzyladenine rate presented in Table 5 revealed that the most effective combinations for enhancing plant height and NAR were $\mathrm{ET}_{100}$ or $\mathrm{ET}_{80}$ whether with $\mathrm{BA}_{200}$ or $\mathrm{BA}_{150}$ in both seasons. Also, $\mathrm{ET}_{100} \times \mathrm{BA}_{100}$ interaction statistically equaled the former remarkable interactions for plant height in 2016 season and NAR in both seasons.

\section{Yield traits and oil and protein percentages}

All yield traits of soybean statistically responded to irrigation and benzyladenine treatments in 2015 and 2016 seasons (Table 6). $\mathrm{ET}_{100}$ was the effective practice for producing higher values of pods number plant ${ }^{-1}$, seed weight plant $^{-1}$, seed yield, oil \% and protein \%. There were no significant variations between $\mathrm{ET}_{100}$ and $\mathrm{ET}_{80}$ for seed yield (in 2015 seasons) and protein \% (in 2016 season). Remarkable reductions in all crop traits were obviously obtained with $\mathrm{ET}_{60}$.

Data presented in Table 6 show the significant increases in pods number plant ${ }^{-1}$, seed weight plant $^{-1}$, seed yield, oil \% and protein \% with increasing BA rates from 0 to $200 \mathrm{mg} \mathrm{L}^{-1}$. The highest values of all these traits were obtained from $\mathrm{BA}_{200}$ along with $\mathrm{BA}_{150}$, except pods number plant $^{-1}$ in both seasons and oil $\%$ in the second season. The relative enhancements due to $\mathrm{BA}_{150}$ compared to untreated control $\left(\mathrm{BA}_{0}\right)$ reached $25.5 \%$ for seed weight plant ${ }^{-1}, 14.3 \%$ for seed yield, $9.2 \%$ for oil $\%$ and $7.2 \%$ for protein $\%$ (as averages of the two seasons).

Concerning the interaction of irrigation level $\mathrm{x}$ benzyladenine rate, the presented values in Table 7 clarify that under $\mathrm{ET}_{100}$, whether with $\mathrm{BA}_{200}$ or $\mathrm{BA}_{150}$ possessed the favorable effects on pods number plant ${ }^{-1}$ and seed yield ha $\mathrm{ha}^{-1}$ in both growing seasons of 2015 and 2016. $\mathrm{ET}_{80} \times \mathrm{BA}_{200}$ (in both seasons) and $\mathrm{ET}_{100} \times \mathrm{BA}_{150}$ (in the first season) were as similar as $\mathrm{ET}_{100} \mathrm{x} \mathrm{BA}_{200}$ for enhancing pods number plant ${ }^{-1}$. Moreover, in 2015 season, $\mathrm{ET}_{80}$ $\mathrm{x} \mathrm{BA}_{150}$ or $\mathrm{BA}_{200}$ and $\mathrm{ET}_{100} \times \mathrm{BA}_{150}$ recorded seed yield values like that of $\mathrm{ET}_{100} \times \mathrm{BA}_{200}$.

\section{Irrigation water use efficiency and regression analysis}

As depicted in Fig. 1, irrigation water use efficiency (IWUE) progressively increased with decreasing irriga- tion water amount and increasing benzyladenine rate. In this regard, the maximum values of IWUE were obtained with $\mathrm{ET}_{60} \times \mathrm{BA}_{200}$ in both seasons and $\mathrm{ET}_{60} \times \mathrm{BA}_{150}$ in

Table 4. Soybean growth parameters as affected by irrigation level and benzyladenine rate in 2015 and 2016 seasons.

\begin{tabular}{lcccccccc}
\hline & $\begin{array}{c}\text { Plant height } \\
\text { Irrigation } \\
\text { x BA }\end{array}$ & $\begin{array}{c}(\mathrm{cm}) \\
\end{array}$ & & SPAD value & $\begin{array}{c}\text { RGR } \\
\left(\mathrm{g} \mathrm{g}^{-1} \text { week }^{-1}\right)\end{array}$ & $\begin{array}{c}\text { NAR } \\
\left(\mathrm{g} \mathrm{cm}^{-2}\right. \\
\left.\text { week }^{-1}\right)\end{array}$ \\
\cline { 2 - 9 } & 2015 & 2016 & 2015 & 2016 & 2015 & 2016 & 2015 & 2016 \\
\hline $\begin{array}{l}\text { Irrigation } \\
\mathrm{ET}_{60}\end{array}$ & $73.4^{\mathrm{c}}$ & $80.9^{\mathrm{b}}$ & $39.1^{\mathrm{c}}$ & $38.6^{\mathrm{c}}$ & $0.503^{\mathrm{b}}$ & $0.532^{\mathrm{b}}$ & $3.74^{\mathrm{c}}$ & $3.76^{\mathrm{b}}$ \\
$\mathrm{ET}_{80}$ & $85.4^{\mathrm{b}}$ & $84.7^{\mathrm{ab}}$ & $41.0^{\mathrm{b}}$ & $39.9^{\mathrm{b}}$ & $0.544^{\mathrm{a}}$ & $0.540^{\mathrm{b}}$ & $3.92^{\mathrm{b}}$ & $3.98^{\mathrm{a}}$ \\
$\mathrm{ET}_{100}$ & $88.4^{\mathrm{a}}$ & $86.6^{\mathrm{a}}$ & $42.4^{\mathrm{a}}$ & $41.8^{\mathrm{a}}$ & $0.578^{\mathrm{a}}$ & $0.576^{\mathrm{a}}$ & $4.08^{\mathrm{a}}$ & $4.16^{\mathrm{a}}$ \\
\hline Benzyladenine & & & & & & & \\
$\mathrm{BA}_{0}$ & $74.7^{\mathrm{d}}$ & $80.9^{\mathrm{c}}$ & $38.1^{\mathrm{d}}$ & $38.1^{\mathrm{c}}$ & $0.530^{\mathrm{a}}$ & $0.480^{\mathrm{d}}$ & $3.70^{\mathrm{c}}$ & $3.60^{\mathrm{d}}$ \\
$\mathrm{BA}_{50}$ & $79.8^{\mathrm{c}}$ & $82.1^{\mathrm{bc}}$ & $39.8^{\mathrm{c}}$ & $39.1^{\mathrm{bc}}$ & $0.530^{\mathrm{a}}$ & $0.513^{\mathrm{c}}$ & $3.80^{\mathrm{bc}}$ & $3.81^{\mathrm{c}}$ \\
$\mathrm{BA}_{100}$ & $83.7^{\mathrm{b}}$ & $83.6^{\mathrm{b}}$ & $41.0^{\mathrm{bc}}$ & $39.7^{\mathrm{b}}$ & $0.546^{\mathrm{a}}$ & $0.556^{\mathrm{b}}$ & $3.90^{\mathrm{bc}}$ & $4.00^{\mathrm{b}}$ \\
$\mathrm{BA}_{150}$ & $86.4^{\mathrm{a}}$ & $86.6^{\mathrm{a}}$ & $42.3^{\mathrm{ab}}$ & $41.5^{\mathrm{a}}$ & $0.552^{\mathrm{a}}$ & $0.590^{\mathrm{a}}$ & $4.03^{\mathrm{ab}}$ & $4.16^{\mathrm{a}}$ \\
$\mathrm{BA}_{200}$ & $87.6^{\mathrm{a}}$ & $87.3^{\mathrm{a}}$ & $43.0^{\mathrm{a}}$ & $42.1^{\mathrm{a}}$ & $0.550^{\mathrm{a}}$ & $0.606^{\mathrm{a}}$ & $4.13^{\mathrm{a}}$ & $4.26^{\mathrm{a}}$ \\
\hline
\end{tabular}

Note: $\mathrm{ET}_{60}, \mathrm{ET}_{80}$, and $\mathrm{ET}_{100}$ : irrigation level at 60,80 and $100 \%$ of crop evapotranspiration, respectively; $\mathrm{B} . \mathrm{A}_{0}, \mathrm{BA}_{50}, \mathrm{BA}_{100}, \mathrm{BA}_{150}$, $\mathrm{BA}_{200}$ : benzyladenine rate of $0,50,100,150$ and $200 \mathrm{mg} \mathrm{L}^{-1}$, respectively; SPAD: total leaf chlorophyll content; RGR: relative growth rate; NAR: net assimilation rate. Means followed by different letters in each column are significantly different $(P<0.05)$.

Table 5. Plant height and net assimilation rate (NAR), of soybean as affected by irrigation level and benzyladenine rate interaction in 2015 and 2016 seasons.

\begin{tabular}{|c|c|c|c|c|c|c|}
\hline \multirow{2}{*}{ Variable } & \multicolumn{3}{|c|}{ Plant height $(\mathrm{cm})$} & \multicolumn{3}{|c|}{$\operatorname{NAR}\left(\mathrm{g} \mathrm{cm}^{-2}\right.$ week $\left.^{-1}\right)$} \\
\hline & $\mathrm{ET}_{60}$ & $\mathrm{ET}_{80}$ & $\mathrm{ET}_{100}$ & $\mathrm{ET}_{60}$ & $\mathrm{ET}_{80}$ & $\mathrm{ET}_{100}$ \\
\hline \multicolumn{7}{|l|}{2015} \\
\hline $\mathrm{BA}_{0}$ & $66.7^{j}$ & $75.0^{\mathrm{h}}$ & $82.3^{\mathrm{f}}$ & $3.50^{\mathrm{e}}$ & $3.70^{\mathrm{de}}$ & $3.90^{\mathrm{bcd}}$ \\
\hline $\mathrm{BA}_{50}$ & $70.3^{\mathrm{i}}$ & $83.3^{\text {ef }}$ & $85.7^{\mathrm{de}}$ & $3.70^{\mathrm{de}}$ & $3.80^{\text {cde }}$ & $3.90^{\mathrm{bcd}}$ \\
\hline $\mathrm{BA}_{100}$ & $75.0^{\mathrm{h}}$ & $87.0^{\mathrm{cd}}$ & $89.0^{\mathrm{bc}}$ & $3.80^{\text {cde }}$ & $3.80^{\text {cde }}$ & $4.10^{\mathrm{abc}}$ \\
\hline $\mathrm{BA}_{150}$ & $77.0^{\mathrm{gh}}$ & $90.3^{\mathrm{ab}}$ & $92.0^{\mathrm{a}}$ & $3.80^{\text {cde }}$ & $4.10^{\mathrm{abc}}$ & $4.20^{\mathrm{ab}}$ \\
\hline $\mathrm{BA}_{200}$ & $78.0^{\mathrm{g}}$ & $91.7^{\mathrm{ab}}$ & $93.0^{\mathrm{a}}$ & $3.90^{\mathrm{bcd}}$ & $4.20^{\mathrm{ab}}$ & $4.30^{\mathrm{a}}$ \\
\hline \multicolumn{7}{|l|}{2016} \\
\hline $\mathrm{BA}_{0}$ & $79.0^{\mathrm{f}}$ & $80.7^{\mathrm{def}}$ & $83.1^{\text {cde }}$ & $3.50^{\mathrm{f}}$ & $3.60^{\mathrm{ef}}$ & $3.70^{\mathrm{def}}$ \\
\hline $\mathrm{BA}_{50}$ & $79.3^{\text {ef }}$ & $82.8^{\text {cdef }}$ & $84.2^{\mathrm{bcd}}$ & $3.70^{\text {def }}$ & $3.80^{\text {def }}$ & $3.90^{\text {cde }}$ \\
\hline $\mathrm{BA}_{100}$ & $80.4^{\text {def }}$ & $84.1^{\mathrm{bcd}}$ & $86.4^{\mathrm{abc}}$ & $3.70^{\mathrm{def}}$ & $4.00^{\mathrm{bcd}}$ & $4.30^{\mathrm{ab}}$ \\
\hline $\mathrm{BA}_{150}$ & $83.0^{\text {cde }}$ & $87.7^{\mathrm{ab}}$ & $89.2^{\mathrm{a}}$ & $3.90^{\text {cde }}$ & $4.20^{\mathrm{abc}}$ & $4.40^{\mathrm{a}}$ \\
\hline $\mathrm{BA}_{200}$ & $83.2^{\mathrm{cd}}$ & $88.5^{\mathrm{a}}$ & $90.1^{\mathrm{a}}$ & $4.00^{\mathrm{bcd}}$ & $4.30^{\mathrm{ab}}$ & $4.50^{\mathrm{a}}$ \\
\hline
\end{tabular}

Note: $\mathrm{ET}_{60}, \mathrm{ET}_{80}$, and $\mathrm{ET}_{100}$ : irrigation level at 60,80 and $100 \%$ of crop evapotranspiration, respectively; $\mathrm{BA}_{0}, \mathrm{BA}_{50}, \mathrm{BA}_{100}, \mathrm{BA}_{150}, \mathrm{BA}_{200}$ : benzyladenine rate of $0,50,100,150$ and $200 \mathrm{mg} \mathrm{L}^{-1}$, respectively; NAR: net assimilation rate. Means followed by different letters in each column are significantly different $(P<0.05)$. 
Table 6. Soybean yield traits, oil \% and protein \% as affected by irrigation level and benzyladenine rate in 2015 and 2016 seasons.

\begin{tabular}{|c|c|c|c|c|c|c|c|c|c|c|}
\hline \multirow{2}{*}{$\begin{array}{l}\text { Irrigation } \\
\mathrm{x} \text { BA }\end{array}$} & \multicolumn{2}{|c|}{ Pods number plant ${ }^{-1}$} & \multicolumn{2}{|c|}{ Seed weight plant ${ }^{-1}$} & \multicolumn{2}{|c|}{ Seed yield (ton ha ${ }^{-1}$ ) } & \multicolumn{2}{|c|}{ Oil \% } & \multicolumn{2}{|c|}{ Protein $\%$} \\
\hline & 2015 & 2016 & 2015 & 2016 & 2015 & 2016 & 2015 & 2016 & 2015 & 2016 \\
\hline \multicolumn{11}{|l|}{ Irrigation } \\
\hline $\mathrm{ET}_{60}$ & $34.8^{\mathrm{c}}$ & $36.5^{c}$ & $15.4^{\mathrm{c}}$ & $16.4^{\mathrm{c}}$ & $3.36^{\mathrm{b}}$ & $3.58^{c}$ & $23.7^{c}$ & $24.0^{c}$ & $33.9^{c}$ & $34.2^{\mathrm{b}}$ \\
\hline $\mathrm{ET}_{80}$ & $41.3^{\mathrm{b}}$ & $41.8^{\mathrm{b}}$ & $17.2^{\mathrm{b}}$ & $18.2^{\mathrm{b}}$ & $3.92^{\mathrm{a}}$ & $3.95^{\mathrm{b}}$ & $25.3^{\mathrm{b}}$ & $25.5^{\mathrm{b}}$ & $35.5^{\mathrm{b}}$ & $36.0^{\mathrm{a}}$ \\
\hline $\mathrm{ET}_{100}$ & $43.8^{\mathrm{a}}$ & $43.8^{\mathrm{a}}$ & $18.8^{\mathrm{a}}$ & $20.4^{\mathrm{a}}$ & $4.16^{\mathrm{a}}$ & $4.17^{\mathrm{a}}$ & $26.7^{\mathrm{a}}$ & $26.6^{\mathrm{a}}$ & $37.5^{\mathrm{a}}$ & $36.5^{\mathrm{a}}$ \\
\hline \multicolumn{11}{|c|}{ Benzyladenine } \\
\hline $\mathrm{BA}_{0}$ & $37.1^{\mathrm{d}}$ & $34.9^{\mathrm{e}}$ & $14.7^{\mathrm{d}}$ & $16.0^{\mathrm{d}}$ & $3.46^{\mathrm{d}}$ & $3.65^{\mathrm{d}}$ & $23.7^{\mathrm{e}}$ & $23.9^{d}$ & $33.6^{\mathrm{d}}$ & $34.3^{c}$ \\
\hline $\mathrm{BA}_{50}$ & $38.6^{\mathrm{c}}$ & $37.8^{\mathrm{d}}$ & $16.0^{c}$ & $17.0^{c}$ & $3.66^{\mathrm{c}}$ & $3.76^{\mathrm{c}}$ & $24.5^{\mathrm{d}}$ & $24.7^{\mathrm{cd}}$ & $35.0^{c}$ & $34.8^{\mathrm{c}}$ \\
\hline $\mathrm{BA}_{100}$ & $40.8^{\mathrm{b}}$ & $41.2^{\mathrm{c}}$ & $17.1^{\mathrm{b}}$ & $18.5^{\mathrm{b}}$ & $3.83^{\mathrm{b}}$ & $3.86^{\mathrm{b}}$ & $25.4^{\mathrm{c}}$ & $25.5^{\mathrm{bc}}$ & $36.0^{\mathrm{b}}$ & $35.8^{\mathrm{b}}$ \\
\hline $\mathrm{BA}_{150}$ & $40.9^{\mathrm{b}}$ & $44.2^{\mathrm{b}}$ & $18.7^{\mathrm{a}}$ & $19.8^{\mathrm{a}}$ & $4.00^{\mathrm{a}}$ & $4.12^{\mathrm{a}}$ & $26.0^{\mathrm{b}}$ & $26.2^{\mathrm{ab}}$ & $36.5^{\mathrm{ab}}$ & $36.3^{\mathrm{ab}}$ \\
\hline $\mathrm{BA}_{200}$ & $42.4^{\mathrm{a}}$ & $45.4^{\mathrm{a}}$ & $19.4^{\mathrm{a}}$ & $20.4^{\mathrm{a}}$ & $4.11^{\mathrm{a}}$ & $4.13^{\mathrm{a}}$ & $26.4^{\mathrm{a}}$ & $26.7^{\mathrm{a}}$ & $37.2^{\mathrm{a}}$ & $36.7^{\mathrm{a}}$ \\
\hline
\end{tabular}

Note: $\mathrm{ET}_{60}, \mathrm{ET}_{80}$, and $\mathrm{ET}_{100}$ : irrigation level at 60,80 and $100 \%$ of crop evapotranspiration, respectively; $\mathrm{BA}_{0}, \mathrm{BA}_{50}, \mathrm{BA}_{100}, \mathrm{BA}_{150}, \mathrm{BA}_{200}$ : benzyladenine rate of $0,50,100,150$ and $200 \mathrm{mg} \mathrm{L}^{-1}$, respectively. Means followed by different letters in each column are significantly different $(P<0.05)$.

Table 7. Pods number plant ${ }^{-1}$ and seed yield of soybean as affected by irrigation level and benzyladenine rate interaction in 2015 and 2016 seasons.

\begin{tabular}{|c|c|c|c|c|c|c|}
\hline \multirow{2}{*}{ Variable } & \multicolumn{3}{|c|}{ Pods number plant ${ }^{-1}$} & \multicolumn{3}{|c|}{ Seed yield (ton $\mathrm{ha}^{-1}$ ) } \\
\hline & $\mathrm{ET}_{60}$ & $\mathrm{ET}_{80}$ & $\mathrm{ET}_{100}$ & $\mathrm{ET}_{60}$ & $\mathrm{ET}_{80}$ & $\mathrm{ET}_{100}$ \\
\hline \multicolumn{7}{|l|}{2015} \\
\hline $\mathrm{BA}_{0}$ & $31.3^{\mathrm{i}}$ & $38.6^{\mathrm{ef}}$ & $41.4^{\mathrm{cd}}$ & $3.10^{\mathrm{i}}$ & $3.50^{\mathrm{fgh}}$ & $3.80^{\text {cde }}$ \\
\hline $\mathrm{BA}_{50}$ & $33.6^{\mathrm{h}}$ & $39.6^{\mathrm{de}}$ & $42.6^{\mathrm{bc}}$ & $3.30^{\mathrm{hi}}$ & $3.70^{\mathrm{def}}$ & $4.00^{\mathrm{bc}}$ \\
\hline $\mathrm{BA}_{100}$ & $36.4^{\mathrm{g}}$ & $41.4^{\mathrm{cd}}$ & $44.5^{\mathrm{ab}}$ & $3.40^{\mathrm{gh}}$ & $3.90^{\mathrm{cd}}$ & $4.20^{\mathrm{ab}}$ \\
\hline $\mathrm{BA}_{150}$ & $35.3^{\mathrm{gh}}$ & $42.2^{\mathrm{c}}$ & $45.3^{\mathrm{a}}$ & $3.40^{\mathrm{gh}}$ & $4.20^{\mathrm{ab}}$ & $4.40^{\mathrm{a}}$ \\
\hline $\mathrm{BA}_{200}$ & $37.3^{\mathrm{fg}}$ & $44.6^{\mathrm{ab}}$ & $45.4^{\mathrm{a}}$ & $3.60^{\text {efg }}$ & $4.30^{\mathrm{a}}$ & $4.40^{\mathrm{a}}$ \\
\hline \multicolumn{7}{|l|}{2016} \\
\hline $\mathrm{BA}_{0}$ & $31.7^{\mathrm{g}}$ & $35.9^{\mathrm{ef}}$ & $37.1^{\mathrm{de}}$ & $3.40^{\mathrm{g}}$ & $3.70^{\mathrm{ef}}$ & $3.85^{\text {cde }}$ \\
\hline $\mathrm{BA}_{50}$ & $33.8^{\mathrm{fg}}$ & $39.0^{\text {cde }}$ & $40.7^{c}$ & $3.51^{g}$ & $3.81^{\text {cde }}$ & $3.97^{\mathrm{c}}$ \\
\hline $\mathrm{BA}_{100}$ & $37.9^{\text {cde }}$ & $41.0^{c}$ & $44.8^{\mathrm{b}}$ & $3.54^{\mathrm{fg}}$ & $3.90^{\mathrm{cd}}$ & $4.14^{\mathrm{b}}$ \\
\hline $\mathrm{BA}_{150}$ & $39.4^{\mathrm{cd}}$ & $45.8^{\mathrm{b}}$ & $47.3^{\mathrm{ab}}$ & $3.76^{\mathrm{de}}$ & $4.19^{\mathrm{b}}$ & $4.44^{\mathrm{a}}$ \\
\hline $\mathrm{BA}_{200}$ & $40.0^{\mathrm{cd}}$ & $47.1^{\mathrm{ab}}$ & $49.1^{\mathrm{a}}$ & $3.72^{\mathrm{e}}$ & $4.19^{\mathrm{b}}$ & $4.45^{\mathrm{a}}$ \\
\hline
\end{tabular}

Note: $\mathrm{ET}_{60}, \mathrm{ET}_{80}$, and $\mathrm{ET}_{100}$ : irrigation level at 60,80 and $100 \%$ of crop evapotranspiration, respectively; $\mathrm{BA}_{0}, \mathrm{BA}_{50}, \mathrm{BA}_{100}, \mathrm{BA}_{150}, \mathrm{BA}_{200}$ : benzyladenine rate of $0,50,100,150$ and $200 \mathrm{mg} \mathrm{L}^{-1}$, respectively. Means followed by different letters in each column are significantly different $(P<0.05)$.

the second season, while $\mathrm{ET}_{100} \times \mathrm{BA}_{0}$ or $\mathrm{BA}_{50}$ recorded the lowest value in both seasons. Despite the similarity of benzyladenine behavior under different irrigation regimes, its relationship strength with IWUE varied (Fig. 2). In this respect, regression analysis showed that benzyladenine rate was more correlated with IWUE under low water supply $\left(\mathrm{ET}_{60}\right)$, since $\mathrm{R}^{2}$ value was higher compared to other irrigation regimes $\left(\mathrm{ET}_{80}\right.$ or $\left.\mathrm{ET}_{100}\right)$.
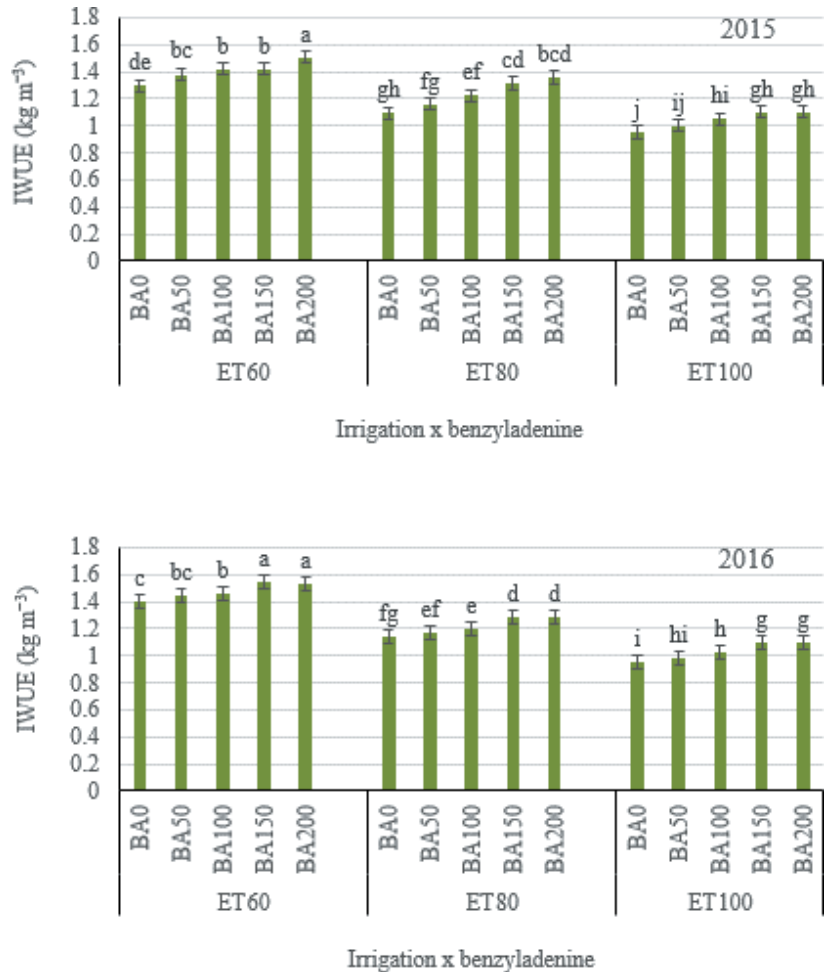

Fig. 1. Irrigation water use efficiency (IWUE) of soybean as influenced by irrigation level and benzyladenine rate. Note: $\mathrm{ET}_{60}, \mathrm{ET}_{80}$, and $\mathrm{ET}_{100}$ : irrigation level at 60,80 and $100 \%$ of crop evapotranspiration, respectively; $\mathrm{BA}_{0}, \mathrm{BA}_{50}, \mathrm{BA}_{100}, \mathrm{BA}_{150}, \mathrm{BA}_{200}$ : benzyladenine rate of $0,50,100,150$ and $200 \mathrm{mg} \mathrm{L}^{-1}$, respectively. Vertical bars represent means of 4 replications \pm SE $(P \leq 0.05)$. Columns marked by different letters are significantly different 


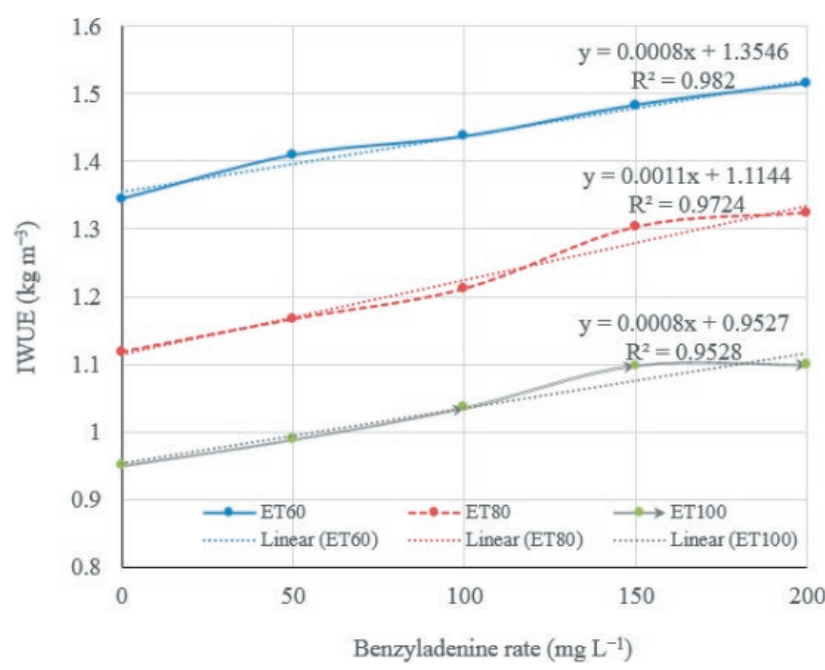

Fig. 2. Regression relationship between irrigation water use efficiency (IWUE) of soybean and benzyladenine rates under different irrigation levels. Note: $\mathrm{ET}_{60}, \mathrm{ET}_{80}$, and $\mathrm{ET}_{100}$ : irrigation level at 60, 80 and $100 \%$ of crop evapotranspiration, respectively.

\section{DISCUSSION}

As well known, supplying plants by water amounts less than required almost caused disorders in plant growth and development. Findings of the current research confirmed that reducing irrigation water by $40 \%$ in soybean mightily caused reduction in growth traits. Accordingly, irrigating soybean by $60 \%$ of crop evapotranspiration $\left(\mathrm{ET}_{60}\right)$ caused reductions (averages of the two seasons) could be amounted to $11.8 \%$ for plant height, $7.8 \%$ for SPAD value, $10.3 \%$ for RGR and $8.4 \%$ for NAR (Table 4). These results might be ascribed to that water stress causes changing in patterns of plant growth and development (Ouda et al. 2010) and disturbance of metabolites transportation within plant (Tayel and Sabreen, 2011). Also, subjecting plants to water amount less than needed may caused reduction in accumulation of assimilates in seeds leading to decreases in yield traits (Table 6). In this respect, De Souza et al. (1997) reported that water stress shortened the seed-filling period resulting 32 and $44 \%$ reductions in seed size and seed yield, respectively. Soybean plants exposed to water stress were characterized by significant decline in photosynthetic rate, stomatal conductance and transpiration rate (Ohashi et al. 2006). Excessive energy in reaction center of photosynthesis apparatus (PSII or PSI) can cause pigment bleaching in sun leaves, as well as can induce photoinhibition, thereby damaging pigments through oxidative stress (Kim et al. 2011; El-Metwally and Saudy 2021). Moreover, plants subjected to drought exhibit large reductions in relative water content of leaves (RWC) and water potential (Dekov et al. 2001; Nayyar and Gupta 2006), leading to dehydration of plant tissue as a result of high light intensity and soil water deficit (Nicolás et al. 2005). Additionally, Zhang et al. (2016) reported that stomata are sensitive to RWC and tend to close with decreasing RWC, which can result in lower stomatal conductance levels in drought-exposed plants. Stomatal closure primarily causes a decline in the photosynthesis rate (Mahajan and Tuteja 2005). Recent studies confirmed the adverse impacts of drought on crop growth and yields (Saudy and El-Metwally 2019; Saudy et al. 2020; Mubarak et al 2021; Saudy et al. 2021). Contrariwise, supplying soybean plants with adequate water requirement might enhance the plant to absorb a larger quantity of nutrients, which leads to increased vegetative growth of plants and increase the plantss ability to intercept the radiation, hence increase the rate of photosynthesis (Tayel and Sabreen 2011, Gkaswa et al. 2014). Accordingly, yield and its attributes of soybean were enhanced by applying $\mathrm{ET}_{100}$ followed by $\mathrm{ET}_{80}$ (Table 6). Furthermore, the differences between $\mathrm{ET}_{100}$ and $\mathrm{ET}_{80}$ were slight and did not exceed $5.1 \%$ for pods number plant $^{-1}, 9.6 \%$ for seed weight plant ${ }^{-1}, 5.4 \%$ for seed yield $\mathrm{ha}^{-1}, 4.6 \%$ for oil $\%$ and $3.3 \%$ for protein $\%$ (averages of the two seasons).

Motivational effect of benzyladenine toward growth and yield of soybean was more evident with elevating its concentration up to $\mathrm{BA}_{200}$ or $\mathrm{BA}_{150}$, improving the performances (Tables 4 and 6). In this regard, BA plays a great role in cell division and cell differentiation, senescence, photosynthetic pigment (Sarwat and EL-Sherif 2007). Plant growth regulators can enhance the sourcesink ratio and catalyze the translocation of photosynthesis assimilates, thereby helping in efficacious flower genesis, fruit and seed development and eventually boost crop productivity. Photosynthetic potentiality and effective partitioning of accumulated substances from source to sink were improved because of growth regulators application (Solamani et al. 2001). A correlation between endogenous levels of cytokinins and the degree of flower abortion and set was reported by Nooden et al. (1990). It is noted that cytokinins regulate flower and pod development in soybean, thus application of exogenous benzyladenine (individual of cytokinins) has been shown to prevent abortion of flowers and/or pods (Reese et al., 1995). The positive effect of benzyladenine spraying may be due to ability to adjust several biological processes owing their ability to influence almost all plant development and growth stages (Plihalova et al. 2016). benzyladenine substantially induced accumulation of total $\mathrm{N}$ and protein synthesis (Taiz and Zeiger 2006; Ayad and Gamal El-Din 2011). 
Despite soybean plants differentiate plentiful floral buds, most of them fail to grow into pods and abort during development. Remarkable abortion of flowers and pods commonly occurs in soybean (Abernethy et al. 1997). Such phenomenon is exactly induced with presence of water stress. Seed abortion began earlier in stressed plants and the duration of the maturation period was significantly reduced, leading to accelerated senescence (Desclaux and Roumet 1996). Because of impairment of ovule function as result of water deficit, soybean flowers aborted (Kokubun et al. 2001). By examining the data in Tables 5 and 7, we can obtain that $\mathrm{ET}_{100} \times \mathrm{BA}_{0}$ interaction (farmer common practice) is more effective for enhancing crop growth and yield traits than $\mathrm{ET}_{80} \times \mathrm{BA}_{0}$ one. However, the values of plant height, NAR, pods number plant ${ }^{-1}$ and seed yield ha ${ }^{-1}$ due to $\mathrm{ET}_{80} \times \mathrm{BA}_{200}$ or $\mathrm{BA}_{150}$ treatments were higher than those of produced with common practice $\left(\mathrm{ET}_{100} \mathrm{X}\right.$ $\mathrm{BA}_{0}$ ). Such finding refers to the beneficial impact of benzyladenine under low water supply conditions. Sharma and Walia (1996) reported that BA may be involved in the development of leaves and branches in plants under adverse conditions such as low drought. Exogenous application of plant hormones i.e. 6-benzyladenine (individual of cytokinins) have been used to improve vegetative growth and yields by foliar applications (Basuchaudhuri 2016). The improvements in plant growth under water stress as a result of benzyladenine application could be attributed to its importance for inducing the antioxidant compounds in treated plants. The application of cytokinins could raise the antioxidants such as phenolics and flavonoids levels (Rahneshan et al. 2018). The potential high antioxidant capacity in plants treated by BA was attributed to the high amounts of phenolics (Mangena 2020). Phenolics are highly potent antioxidants and free-radical scavengers owing to their capacity as strong reducing agents (Chandra et al. 2014). Similar result was obtained by Hassanein et al. (2005) and Ahmed et al. (2016).

Calculation of IWUE confirmed the beneficial effect of benzyladenine under severe stress, moderate stress or well-watered circumstance (Fig. 1), since its application regulate the ratio of soybean seed yield to applied water. In this situation, the increase in IWUE associated increasing benzyladenine rates refers to better exploiting each water drop to produce dry biomass. By comparing the efficiency of benzyladenine under different irrigation regimes, regression analysis (Fig. 2) forecasted that the more the rate of benzyladenine increases by one unit the more the IWUE increases by $0.0008,0.0011$ and 0.0008 units with $\mathrm{ET}_{60} \mathrm{ET}_{80} \mathrm{ET}_{100}$, respectively. From $\mathrm{R}^{2}$ value of each, it is noticed that the importance of benzyladenine is more evi- dent in exhibiting changes in IWUE under severe stress $\left(\mathrm{ET}_{60}\right)$, since $98.2 \%$ of these changes occurred. Accordingly, application of benzyladenine at a rate of 150 or 200 $\mathrm{mg}^{-1}$ is so useful under moderate water supply.

\section{CONCLUSION}

Our findings proved that benzyladenine had the potentiality to enhance crop growth and yield under severe drought $\left(\mathrm{ET}_{60}\right)$, moderate drought $\left(\mathrm{ET}_{80}\right)$ and non drought $\left(\mathrm{ET}_{100}\right)$ conditions. Moreover, the values of plant height, net assimilation rate, pods number plant $^{-1}$ and seed yield ha ${ }^{-1}$ obtained with $\mathrm{ET}_{80} \times \mathrm{BA}_{200}$ or $\mathrm{BA}_{150}$ treatments were higher than those of produced with common farmers practice $\left(\mathrm{ET}_{100} \times \mathrm{BA}_{0}\right)$. As well, the reduction in seed yield due to lowering water supply by $20 \%$ (moderate drought) can be compensated using benzyladenine, $150 \mathrm{mg} \mathrm{L}^{-1}$. Thus, benzyladenine should be involved in the various irrigation programs of soybean. Also, even if there is more available water in the area, farmers are exhorted to use moderately water-stressed plus benzyladenine pattern viz $\mathrm{ET}_{80} \times \mathrm{BA}_{150}$ treatment with saving $20 \%$ of irrigation water quantity which can be exploited for irrigating other lands. Hence, the treatment of $\mathrm{ET}_{80} \times \mathrm{BA}_{150}$ may consider an auspicious practice under areas suffering from water shortage for soybean crop production. However, several studies should be implemented to confirm the potency of benzyladenine in altering the physiological/biochemical response involving complex and variable metabolic pathways forming different metabolites in soybean.

\section{ACKNOWLEDGEMENTS}

Technical supports provided by the Faculty of Agriculture, Ain Shams University and National Research Centre, Egypt are acknowledged.

\section{AUTHOR CONTRIBUTIONS}

Conception and design of the study: Ibrahim Mohamed El-Metwally and Hani Saber Saudy. Acquisition of data for the study: Ibrahim Mohamed El-Metwally and Magdi Tawfik Abdelhamid. Analysis of data for the work: Hani Saber Saudy. Interpretation of data for the work: Ibrahim Mohamed El-Metwally and Magdi Tawfik Abdelhamid. Manuscript revision and approval: Ibrahim Mohamed El-Metwally, Magdi Tawfik Abdelhamid and Hani Saber Saudy. 


\section{REFERENCES}

Abernethy R, Palmer, RG, Shibles RM, Anderson IC. 1997. Histological observations on abscising and retained soybean flowers. Cana. J Plant Sci. 57:713716.

Ahmed MA, Bakhoum Gehan Sh, EL-Housini Ebtesam A, Badr Elham A. 2016. Alleviation of water stress on wheat by Benzyl adenine. Inter J PharmTech Res. 9:109-119.

Allen RG, Pereira LS, Raes D, Smith M. 1998. Crop evapotranspiration-guidelines for computing crop water requirements-FAO irrigation and drainage paper 56, Rome, Italy.

AOAC 2012. Official Method of Analysis: Association of Analytical Chemists. 19th Edition, Washington DC, USA.

Ayad HS, Gamal EL-Din, KM. 2011. Effect of atomic and Benzyl adenine on growth and some biochemical constituents of Lupine plant (Lupinns termis L). Amer-Euras J Agric Environ Sci. 10:519-524.

Basuchaudhuri P. 2016. Influences of plant growth regulators on yield of soybean. Ind J Plant Sci. 5:25-38.

Borges LP, Torres Junior HD, Neves TG, Cruvinel CKL, Santos PGF, Matos FS. 2014. Does benzyladenine application increase soybean productivity? Afr J Agric Res. 9:2799-2804.

Casella G (2008) Statistical Design. 1st ed. Springer, Gainesville, FL 32611-8545, USA.

Chandra S, Khan S, Avula B, Lata H, Yang MH, ElSohly MA, Khan IA. 2014. Assessment of total phenolic and flavonoid content, antioxidant properties, and yield of aeroponically and conventionally grown leafy vegetables and fruit crops: a comparative study. Evidence-Based Complem Alter Med. Article ID 253875, 9p. https://doi.org/10.1155/2014/253875

De Souza PI, Egli DB, Bruening WP. 1997. Water stress during seed filling and leaf senescence in soybean. Agron J. 89:807-812.

Dekov I, Tsonev T, Yordanov I. 2001. Effects of water stress and high-temperature stress on the structure and activity of photosynthetic apparatus of Zea mays and Helianthus annuus. Photosynth. 38:361-366.

Desclaux D, Roumet P. 1996. Impact of drought stress on the phenology of two soybean (Glycine max L. Merr) cultivars. Field Crops Res. 46:61-70.

Dogan E, Kirnak H, Copur O. 2007. Deficit irrigation during soybean reproductive stages and CRPGROsoybean simulations under semi-arid climatic conditions. Field Crops Res. 103:154-159.

Draper NR, Smith H. 1998. Applied Regression Analysis, $3^{\text {rd }}$ Ed. John Wiley \& Sons, New York.
El-Bially MA, Saudy HS, El-Metwally IM, Shahin MG. 2018. Efficacy of ascorbic acid as a cofactor for alleviating water deficit impacts and enhancing sunflower yield and irrigation water-use efficiency. Agric Water Manage. 208: 132-139.

El-Metwally IM, Geries L, Saudy HS. 2021. Interactive effect of soil mulching and irrigation regime on yield, irrigation water use efficiency and weeds of trickleirrigated onion. Archiv Agron Soil Sci <https://doi. org/10.1080/03650340.2020.1869723>

El-Metwally IM, Saudy HS. 2021. Interactional impacts of drought and weed stresses on nutritional status of seeds and water use efficiency of peanut plants grown in arid conditions. Gesunde Pflanzen 73:407-416 <https://doi.org/10.1007/s10343-021-00557-3>

Gkaswa SL, Dubey RK, Singh S, Tiwari RC. 2014. Growth, product and quality of soybean (Glycine $\max$ L.) under different levels and sources of phosphorus and plant growth regulators in sub humid Rajasthan. Afr J Agric Res. 9:1045-1051.

Hassanein RA, Khattab HKI, EL-Bassiouny HMS, Sadak MS. 2005. Increasing the active constituents of sepals of roselle (Hibiscus sabdariffa L.) plant by applying gibberellic acid and benzyladenine. J App Sci Res. 1:137-146.

Hunt R. 1982. Plant growth curves: The functional approach to plant growth analysis. London, Edward Arnold, p:14-46.

Keller J, Bliesner RD. 1990. Sprinkle and Trickle Irrigation. AVI Book. Van Nostrand Reinhold, New York.

Khaswa SL, Dubey RK, Singh S, Tiwari RC. 2014. Growth, productivity and quality of soybean (Glycine $\max ($ L.) Merr.) under different levels and sources of phosphorus and plant growth regulators in Subhumid Rajasthan. Afr J Agric Res. 9:1045-1051.

Kim SJ, Yu DJ, Kim TC, Lee HJ. 2011. Growth and photosynthetic characteristics of blueberry (Vaccinium corymbosum cv. Bluecrop) under various shade levels. Scientia Hort. 129:486-492.

Kokubun M, Shimada S, Takahashi M. 2001. Flower abortion caused by preanthesis water deficit is not attributed to impairment of pollen in soybean. Crop Sci. 41:1517-1521.

Mahajan S, Tuteja N. 2005. Cold, salinity and drought stresses: an overview. Arch Biochem Biophysics. 444:139-158.

Mangena P. 2020. Role of Benzyladenine Seed Priming on Growth and Physiological and Biochemical Response of Soybean Plants Grown under High Salinity Stress Condition. Int J Agron. Article ID 8847098, 5p. https://doi.org/10.1155/2020/8847098

Minolta. 1989. Chlorophyll meter SPAD-502. Instruction manual. Osaka: Minolta Co., Ltd., Radiometric Instruments Operations. 
Mubarak M, Salem EMM, Kenawey MKM, Saudy HS. 2021. Changes in calcareous soil activity, nutrient availability, and corn productivity due to the integrated effect of straw mulch and irrigation regimes. J Soil Sci Plant Nutr 21:2020-2031. <https://doi. org/10.1007/s42729-021-00498-w>

Nakagawa ACS, Ario N, Tomita Y, Tanaka S, Murayama N, Mizuta C, Iwaya-Inoue M, Ishibashi Y 2020. High temperature during soybean seed development differentially alters lipid and protein metabolism, Plant Prod Sci. 23:504-512. DOI: 10.1080/1343943X.2020.1742581

Nayyar H, Gupta D. 2006. Differential sensitivity of C3 and $\mathrm{C} 4$ plants to water deficit stress: association with oxidative stress and antioxidants. Environ Exp Bot. 58:106-113.

Nicolás E, Torrecillas A, DellAmico J, Alarcón JJ. 2005. Sap flow, gas exchange, and hydraulic conductance of young apricot trees growing under a shading net and different water supplies. J Plant Physiol. 162:439-447.

Nooden ID, Santo KRS, Letham DS. 1990. Correlation of xylem sap cytokinin levels with monocarpic senescence in soybean. Plant Physiol. 93:33-39.

Ohashi Y, Nakayama N, Saneoka H, Fujita K. 2006. Effects of drought stress on photosynthetic gas exchange, chlorophyll fluorescence and stem diameter of soybean plants. Biol Planta. 50:138-141.

Ouda SA, Shreif MA, Abou Elenin R. 2010. Increasing water productivity of faba bean grown under deficit irrigation at middle Egypt. Fourteenth International Water Technology Conference, IWTC 14, Cairo, Egypt. pp:45-55.

Oweis T, Hachum AY. 2003. Improving water productivity in the dry areas of west Asia and North Africa. In KIJNE, J.W. BARKER, R. MOLDEN, D. (Eds.) Water productivity in agriculture: limits and opportunities for improvement. CAB International. pp:179-198.

Plihalova L, Vylicilova H, Dolezal K, Zahajska L, Zatloukal M, Strand M. 2016. Synthesis of aromatic cytokinins for plant biotechnology. New Tech. 33:614624.

Rademacher W. 2015. Plant growth regulators: Backgrounds and uses in plant production. J Plant Growth Regul. 34:845-872.

Rahneshan Z, Nasibi F, Moghadam AA. 2018. Effects of salinity stress on some growth, physiological, biochemical parameters and nutrients in two pistachio (Pistacia vera L.) rootstocks. J Plant Interac. 13:73-82.

Reese RN, Dybing CD, White CA, Page SM, Larson JE. 1995. Expression of vegetative storage protein (VSP- $\beta$ ) in soybean raceme tissues in response to flower set. J Exp Bot. 46:957-964.
Reisdorph NA, Koster KI. 1999. Progressive loss of desiccation tolerance in germinating pea (Pisum sativum) seeds. Physiol Planta 105:266-271.

Sarwat MI, EL-Sherif MH. 2007. Increasing salt tolerance in some barley genotypes (Hordeum vulgare) by using kinetin and benzyl adenine. World J Agric Sci. 3:617-629.

Salem EMM, Kenawey MKM., Saudy HS, Mubarak M. 2021. Soil mulching and deficit irrigation effect on sustainability of nutrients availability and uptake, and productivity of maize grown in calcareous soils. Comm Soil Sci Plant Anal 52:1745-1761. <https:// doi.org/10.1080/00103624.2021.1892733>

Saudy HS, El-Bially M, El-Metwally IM, Shahin MG. 2021. Physio-biochemical and agronomic response of ascorbic acid treated sunflower (Helianthus Annuus) grown at different sowing dates and under various irrigation regimes. Gesunde Pflanzen 73:169-179. <https://doi.org/10.1007/s10343-020-00535-1>

Saudy HS, El-Metwally IM, Abd El-Samad GA. 2020. Physio-biochemical and nutrient constituents of peanut plants under bentazone herbicide for broad-leaved weed control and water regimes in dry land areas. J Arid Land 12:630-639. https://doi. org/10.1007/s40333-020-0020-y

Saudy HS, El-Metwally IM. 2019. Nutrient utilization indices of NPK and drought management in groundnut under sandy soil conditions. Comm Soil Sci Plant Anal 50:1821-1828. https://doi.org/10.1080/001 03624.2019 .1635147

Sharma K, Walia N. 1996. Growth and yield of soybean (Glycine $\max$ (L.) Merr.) as influenced by light and cytokinin. Environ Ecol. 14:307-310.

Sheteiwy MS, Ali DFI., Xiong YC, Brestic M, Skalicky M, Hamoud YA, Ulhassan Z, Shaghaleh H, AbdElgawad H, Farooq M, Sharma A, El-Sawah AM 2021. Physiological and biochemical responses of soybean plants inoculated with Arbuscular mycorrhizal fungi and Bradyrhizobium under drought stress. BMC Plant Biol 21, 195. https://doi.org/10.1186/s12870-02102949-Z

Soares LH, Dourado Neto D, Fagan EB, Teixeira VF, Pereira IS. 2017. Physiological, phenometric and productive changes in soybean crop due to the use of kinetin. Pesquisa Agro Trop. 47:80-86.

Sofo A, Dichio B, Montanaro G, Xiloyannis C. 2009. Shade effect on photosynthesis and photoinhibition in olive during drought and rewatering. Agric Water Manage. 96:1201-1206.

Solamani A, Sivakumar C, Anbumani S, Suresh T, Arumugam K. 2001. Role of plant growth regulators on rice production: A Review. Agric Rev. 23:33-40. 
Taiz L, Zeiger E. 2006. Plants physiology, 4th Ed. Sinauer Associates Inc. Publishers, Sunder land, Massachusetts, USA.

Tayel MY, Sabreen KhP. 2011. Effect of irrigation regimes and phosphorus level on two Vica faba varieties: 1Growth characters. J App Sci Res. 7:1007-1015.

Tian X, Zhang K, Liu S, Sun X, Li X, Song J, Qi Z, Wang Y, Fang Y, Wang J, Jiang S, Yang C, Tian Z, Li W-X, Ning H 2020. Quantitative trait locus analysis of protein and oil content in response to planting density in soybean (Glycine max (L.) Merri.) seeds based on SNP linkage mapping. Front Genet. 11:563. doi: $10.3389 /$ fgene.2020.00563

Wei Y, Jin J, Jiang S, Ning S, Liu L. 2018. Quantitative response of soybean development and yield to drought stress during different growth stages in the Huaibei Plain, China. Agron 8:97.

Yeh S, Chen H, Ng C, Lin C, Tseng T, Li W, Ku, MSB. 2015. Down-regulation of cytokinin oxidase 2 expression increases tiller number and improves rice yield. Rice. 8:1-13.

Zhang J, Liu J, Yang C, Du S, Yang W 2016. Photosynthetic performance of soybean plants to water deficit under high and low light intensity. South Afr J Bot 105:279-287. 